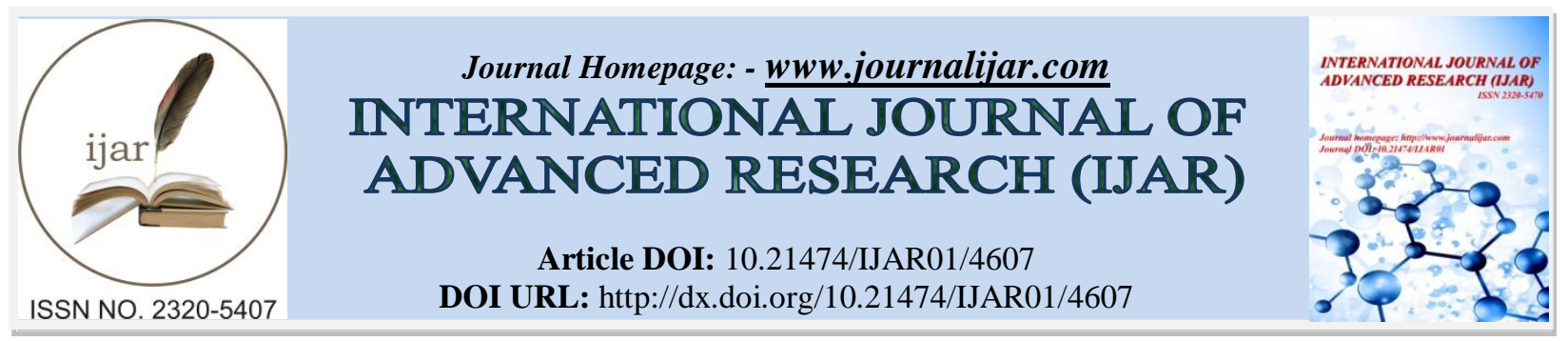

RESEARCH ARTICLE

\title{
UTILISATION OF HOT METAL DESULPHURISED SLAG IN SINTER MAKING AT JSW STEEL
} LIMITED.

\author{
Mr Sharanappa Kalshetty ${ }^{1}$, Dr Rudramuniappa $\mathbf{M V}^{2}$ and Mr Ratnakar Bonda ${ }^{3}$. \\ 1. Assistant General Manager, JSW Steel Limited, Toranagallu, Karnataka. \\ 2. Professor, VSKUB University, PG Centre, Nandihalli, Sandur. \\ 3. Junior Manager, JSW Steel Limited, Toranagllu, Karnataka.
}

\section{Manuscript Info}

Manuscript History

Received: 25 April 2017

Final Accepted: 27 May 2017

Published: June 2017

Key words:-

HMDS, Design, Optimization, HMDShot metal desulphurization station, BOFBasic Oxygen Furnace, LD -Linz and Bonavitz

\section{Abstract}

In BOF, hot metal is converted into steel. Sulphur can be reduced in blast furnace / Corex, but it will be having detrimental effect on plant economy. The generation of steel melting slag are $200-220 \mathrm{~kg} / \mathrm{t}$ of steel produced. Disposal of large quantities of slag becomes a big environmental concern. Slag from steel making has free $\mathrm{CaO}$, which can replace some amount of flux in Iron Making burden. But due to high Phosphorous content in LD slag, it is proposed to use the pre treatment slag which has same $\mathrm{CaO}$ content and less Phosphorous. HMDS slag consists of 2-2.5\% sulphur and same slag used in lab scale to see the impact on sinter quality. Analysis of sinter shown decrease in sulphur up to $0.010 \%$. Hence its is desired to use HMDS slag as substituent to LD Slag in iron ore sinter making which is being used since inception and usage is restricted due to phosphorous content . Thus, recycling of HMDS slag through the sintering process recovers lime, iron and magnesia and thereby saving of flux material and iron ore in future. Detailed investigation was carried out through lab scale studies for estimating the maximum permissible limits of usage of HMDS slag in sinter making and to know the influence of addition on sinter productivity and properties. Statistical Design of Experiments was conducted using the HMDS slag in sinter making from 0 to $60 \mathrm{~kg} / \mathrm{t}$ of sinter. From the test results it was found that 30 to $35 \mathrm{~kg}$ HMDS slag can be used per ton of sinter to get desired properties of the sinter. Results are $30 \%$ of HMDS with $-5 \mathrm{~mm}(5.9$ $\%), 48.14 \%(+10 \mathrm{~mm})$ Tumbler Index (67.12) with $<0.004 \%$ of phosphorous.

Copy Right, IJAR, 2017,. All rights reserved.

\section{Introduction:-}

Integrated steel plants utilize mostly five materials such as raw materials, air, water, fuel and power to produce steel. In an integrated steel plant, during the production of steel, 2-4 tons of wastes are generated per ton of steel produced. Accordingly, present day thrust [1-5] is on reduction of the waste generation, recycling and reuse of waste, and minimizing adverse impact of disposal on environment. Slags generated at iron making and steel making units are the largest quantities among all the solid/liquid wastes. Disposal of large quantities of slag becomes a big environmental concern. Slag handling, disposal and its reuse has become a critical environmental issue for steel 
producers. At present generation of slag has reduced due to improvements in process technologies and its functions. At the same time, the re-use of iron and steelmaking slags has also been expanded, and has led to a significant reduction in the environmental impact of these by products [6-10]. However slag generation remains an unavoidable step and focus on its re-cycling remains the greatest concern.

Steel plant slags mainly include, blast furnace slag and steel melting slag (LD process slag). HMDS Slag is a by product of steel industry, which is generated during pre-treatment of Hot Metal before it is charged into LD converters for Steel Making. The by products usually contain considerable quantities of Oxides of other elements like Fe, Si, Mn \& Ca. Most of the materials of steel plant wastes are recycled through sinter making in most of the countries. Because of its physical, chemical and mineralogical properties, it can be used as raw material in process like sintering. Recycling of HMDS Slag has the highest cost implication on sintering process. HMDS Slag contains high amount of $\mathrm{CaO}$, iron, and $\mathrm{MgO}$, thus recycling it through sintering process helps in the saving of flux and iron ore. The recycled wastes have some effect on sinter quality, strength and productivity. JSW Steel Limited is a 12.0 Mtpa integrated steel plant and produces 1400 to 1500 tons of HMDS Slag per day. Laboratory pot grate sintering experimentation has been carried out to study the effect of HMDS Slag addition on sinter productivity, and physical and metallurgical properties. The HMDS Slag in the sinter mix was varied from 0 to $60 \mathrm{~kg} / \mathrm{t}$ of sinter.

\section{HMDS Slag generation at JSW Steel:-}

HMDS Slag is a waste material (by product) generated in process of steel making. Figure 1 shows the Steel making process and HMDS Slag generation at JSW Steel limited. JSW Steel Limited is a 12 Mtpa integrated steel plant and produces 3200 tons of steel making slag per day and in that HMDS Slag is 1400 to 1500 t/day. This HMDS Slag consists of $45.75 \% \mathrm{CaO}, 22.0 \% \mathrm{Fe}$ and $8.22 \% \mathrm{MgO}$. Thus, recycling of HMDS Slag through the sintering process recovers lime, iron and magnesia and thereby saving of flux material and iron ore. Due to high content of $\mathrm{CaO}$ one can replace HMDS Slag by limestone in sintering process. At present most of the steel plants in the world are reusing HMDS Slag as a flux instead of limestone in sinter making. At JSW Steel Limited steel making slag is completely dumped or used for ground filling after crushing. Based on the earlier trials at JSW steel making slag is being used up to $40 \mathrm{~kg} / \mathrm{t}$ in COREX and $50 \mathrm{~kg} / \mathrm{t}$ in blast furnace. However with the increasing capacities, amount of disposal of huge amount of steel slag is a real challenge. To utilize HMDS Slag in sinter making basic studies are required to know the influence of HMDS Slag addition on sinter chemistry, productivity and sinter properties. The higher phosphorus content in the HMDS Slag is the main restricting factor for utilizing in the sinter making. To optimize the HMDS Slag in sinter making trials have been planned in lab scale and varied the HMDS Slag in the sinter mix from 0 to $60 \mathrm{~kg} / \mathrm{t}$ of sinter. Figure 2 shows the disposal of HMDS Slag at slag yard.

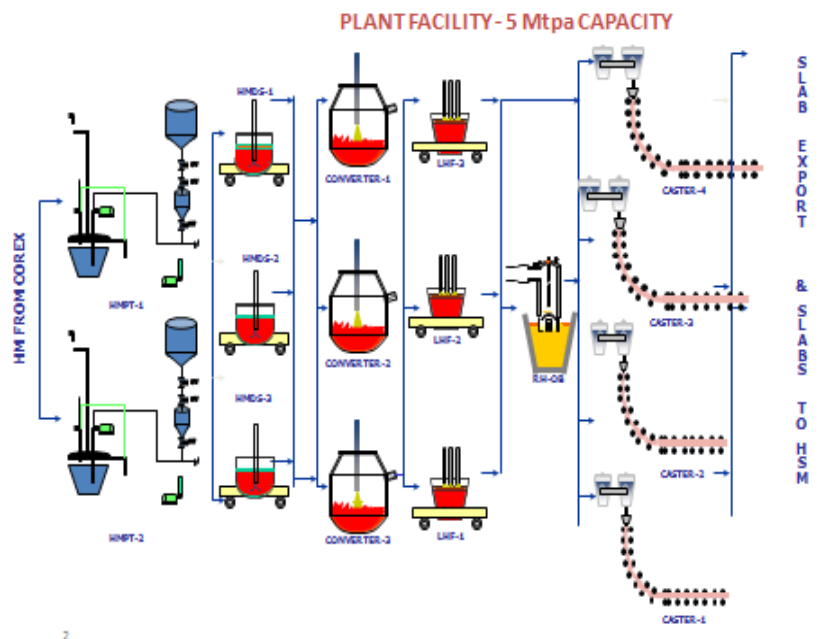

Figure 1:- Steel making Shop-1 process and HMDS Slag generation at JSW Steel limited

Pot grate sintering experiments were carried out in laboratory by using the same raw materials which are used in the sinter plant. The crushed HMDS Slag of $-6 \mathrm{~mm}$ size was collected from the slag yard of steel making shop. The chemical composition of the raw materials which are used in the pot test is given in Table 1. The coke breeze which is a byproduct of coke oven plant is used as fuel. Size distribution of raw material is shown in Table 2. 
In total 7 experiments were carried out by varying the HMDS Slag addition from 0 to $60 \mathrm{~kg} / \mathrm{t}$ in sinter base mix. The basicity and $\mathrm{MgO}$ was kept constant for all experiments. The target sinter chemistry and the base mix proportion for the pot tests are shown in Table 3 and Table 4 respectively. Small piles were prepared by layering the iron ore fines, coke breeze, limestone, dolomite, burnt lime and return fines and HMDS Slag on weight basis (Table 4).

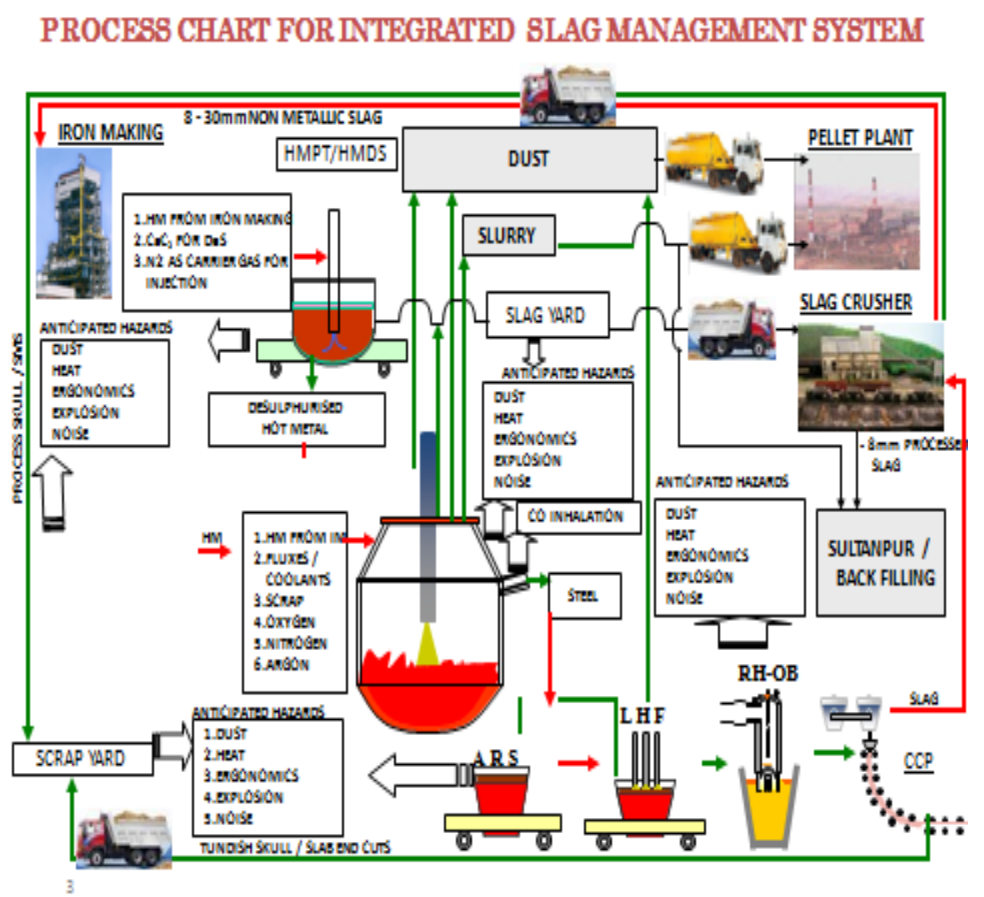

Figure 2:- Process Chart for Integrated Slag Management System

\section{Experimental:-}

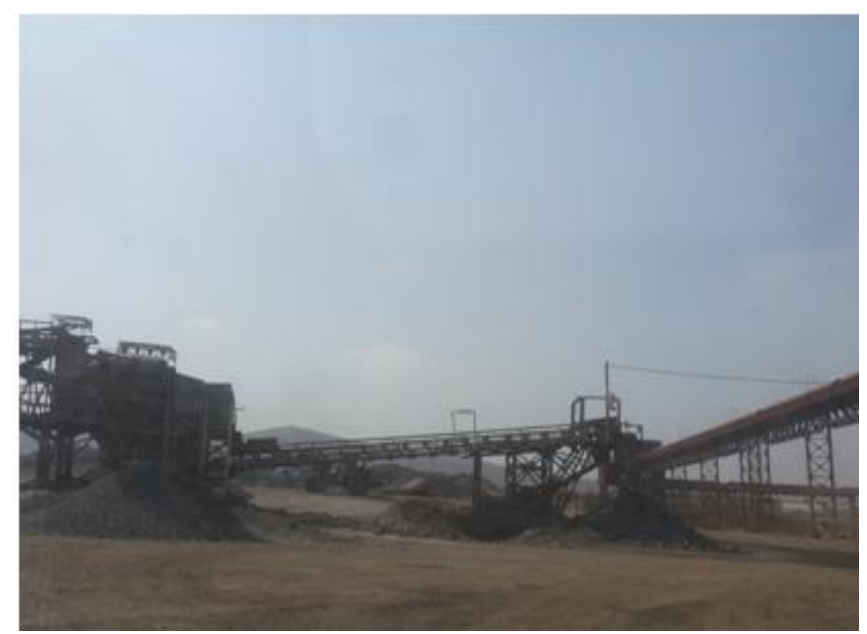

Figure 3:- Disposed HMDS slag at slag yard

All these constituents were thoroughly mixed. After ensuring proper mixing of these raw materials, the base was transferred to the granulation drum. Granules were prepared in the granulation drum by maintaining a granulation time of 7 minutes. The time required for different actions in the granulation cycle is as follows: Dry mixing -2 min; water addition: $2 \mathrm{~min}$; granulation $-3 \mathrm{~min}$. The raw mixture having a weight of $70 \mathrm{~kg}$ was granulated with $8 \%$ moisture. After granulation, the material from the granulation drum was transferred to the sinter pot having an inner diameter of $300 \mathrm{~mm}$ and a height of $600 \mathrm{~mm}$ and subsequently sintered in the pot under a suction of $1300 \mathrm{~mm}$ of WG. The sintering conditions were kept constant for all the experiments. The pot grate test conditions are given in Table 
5 and the experimental setup is shown in Figure 3. Chemical analyses of the raw material as well as sinter products were carried out by using XRF.

Table 1:- Chemical analysis of raw material.

\begin{tabular}{|c|c|}
\hline Details & Chemistry \\
\hline IRON ORE & 50.32 \\
\hline LIME STONE & 8.39 \\
\hline DOLOMITE & 7.12 \\
\hline CALCINED LIME & 0.9 \\
\hline COKE BREEZE & 5.27 \\
\hline BFR & 18 \\
\hline HMPT SLAG & 0 \\
\hline FeO & 65.94 \\
\hline P & 0.04 \\
\hline Sintering Time & 27 \\
\hline TI \% & 67 \\
\hline AI \% & 7.93 \\
\hline Sulphur & 0.004 \\
\hline
\end{tabular}

Table 3:- Target Sinter Chemistry

\begin{tabular}{|c|c|}
\hline Composition & Wt \% \\
\hline $\mathrm{CaO}$ & $<\mathbf{1 3 . 0}$ \\
\hline $\mathrm{MgO}$ & $\mathbf{2 . 2 0}$ \\
\hline $\mathrm{B}_{2}\left(\mathrm{CaO} / \mathrm{SiO}_{2}\right)$ & $\mathbf{2 . 0 0}$ \\
\hline
\end{tabular}

Table 4:- Raw material mix proportion

\begin{tabular}{|c|c|c|c|c|c|c|c|}
\hline \multirow{2}{*}{ Details } & \multicolumn{7}{|c|}{ HMDS Slag Kg/Sinter } \\
\cline { 2 - 7 } & 0 & 10 & 20 & 30 & 40 & 50 & 60 \\
\hline IRON ORE & 50.32 & 50.09 & 49.87 & 49.55 & 49.32 & 49.12 & 48.84 \\
\hline LIME STONE & 8.39 & 8.07 & 7.79 & 7.59 & 7.33 & 7.06 & 6.81 \\
\hline DOLOMITE & 7.12 & 6.87 & 6.57 & 6.29 & 5.97 & 5.68 & 5.34 \\
\hline CALCINED LIME & 0.9 & 0.9 & 0.9 & 0.9 & 0.9 & 0.9 & 0.9 \\
\hline COKE BREEZE & 5.27 & 5.3 & 5.31 & 5.34 & 5.35 & 5.36 & 5.38 \\
\hline BFR & 18 & 18 & 18 & 18 & 18 & 18 & 18 \\
\hline HMPT SLAG & 0 & 0.77 & 1.56 & 2.33 & 3.15 & 3.88 & 4.73 \\
\hline FeO & 65.94 & 66.72 & 67.33 & 65.60 & 64.84 & 67.20 & 66.81 \\
\hline P & 0.04 & 0.046 & 0.057 & 0.045 & 0.041 & 0.05 & 0.066 \\
\hline Sintering Time & 27 & 27 & 29 & 30 & 32 & 31 & 30 \\
\hline TI \% & 67 & 66.47 & 67.8 & 67.27 & 68.67 & 68.87 & 67.33 \\
\hline AI \% & 7.93 & 7.4 & 7.46 & 7.93 & 7.33 & 7.80 & 8.80 \\
\hline Sulphur \% & 0.004 & 0.007 & 0.007 & 0.005 & 0.004 & 0.004 & 0.006 \\
\hline
\end{tabular}

Table 5:- Pot grate sinter test conditions.

\begin{tabular}{|c|c|}
\hline Parameter & Magnitude \\
\hline Bed height, $\mathrm{mm}$ & 600 \\
\hline Hearth layer, $\mathrm{mm}$ & 50 \\
\hline Suction, mm of WC & 1300 \\
\hline${\text { Ignition Temperature, }{ }^{\circ} \mathrm{C}}^{\mathrm{I}}$ & 1150 \\
\hline Ignition time, sec & $120 \mathrm{sec}$ \\
\hline Moisture content, $\%$ & 8 \\
\hline
\end{tabular}




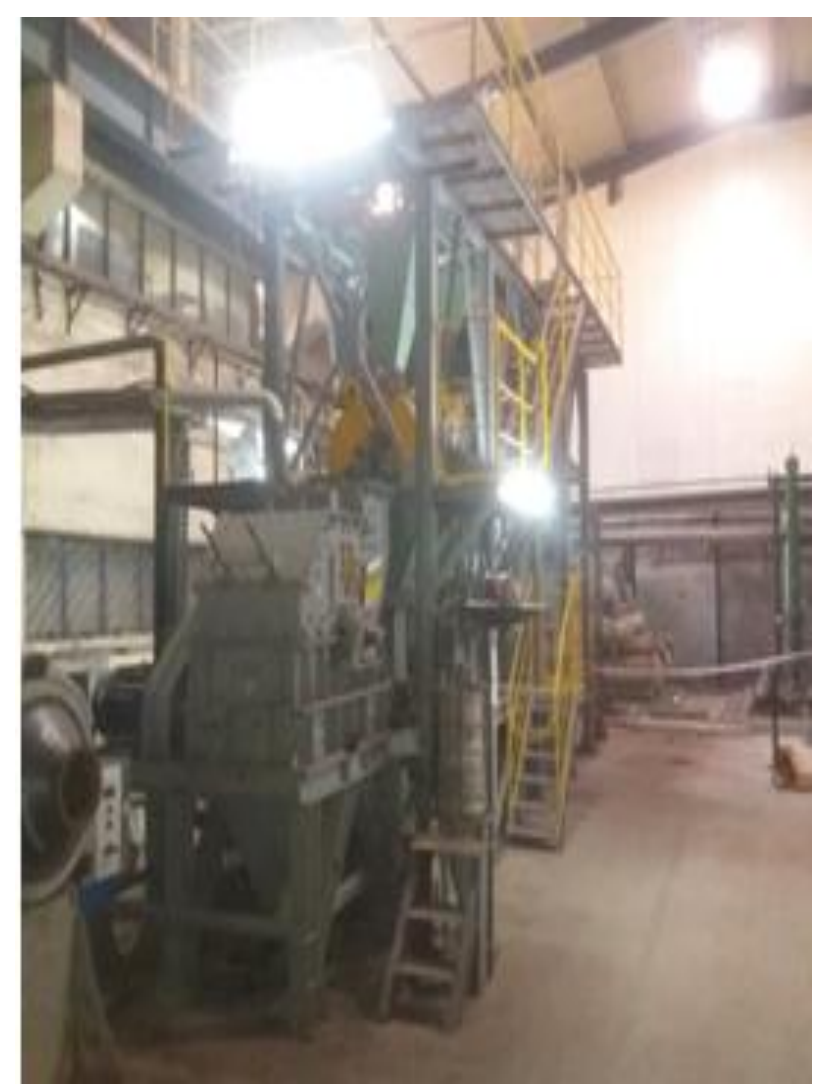

Figure 4:- Pilot Scale Pot grate sintering machine

\section{Results and Discussions:-}

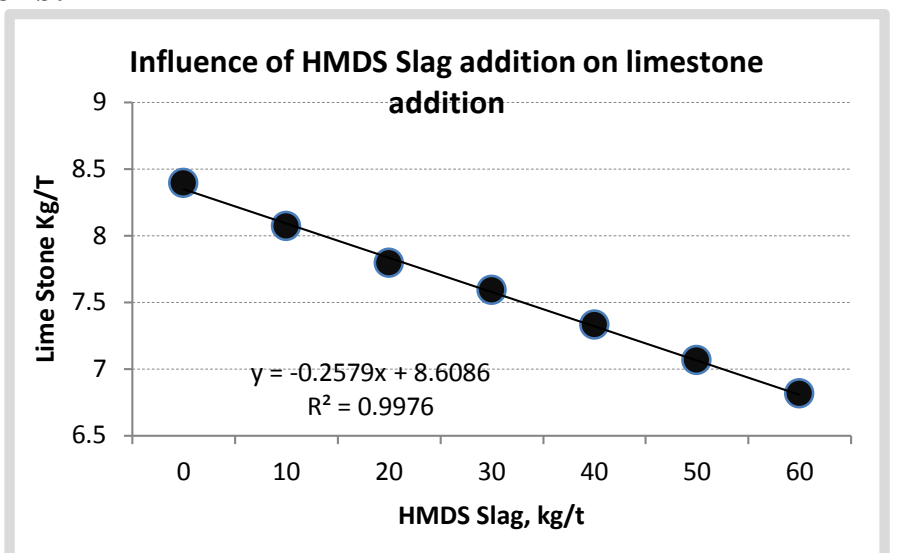

Figure 6:- Influence of HMDS Slag addition on limestone Addition. 


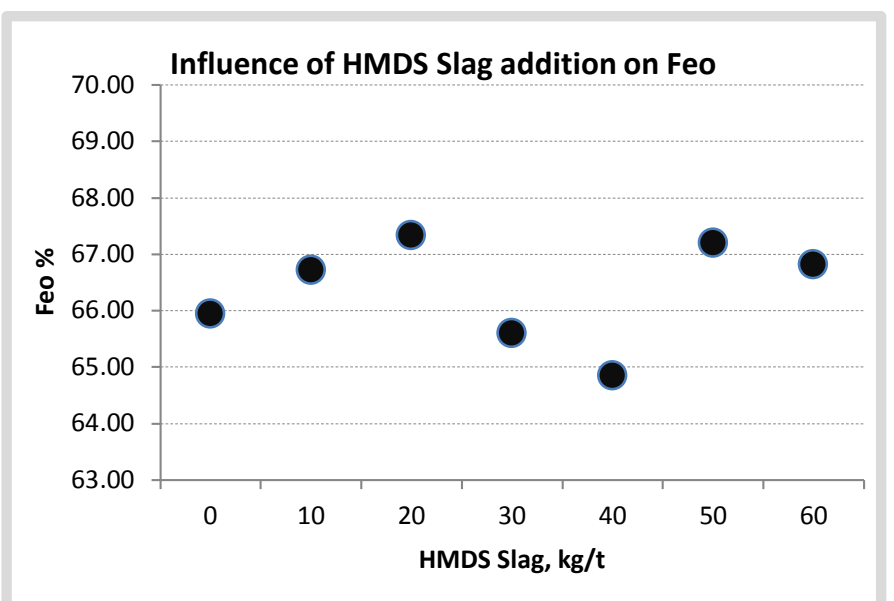

Figure 7:- Influence of HMDS Slag addition on Feo.

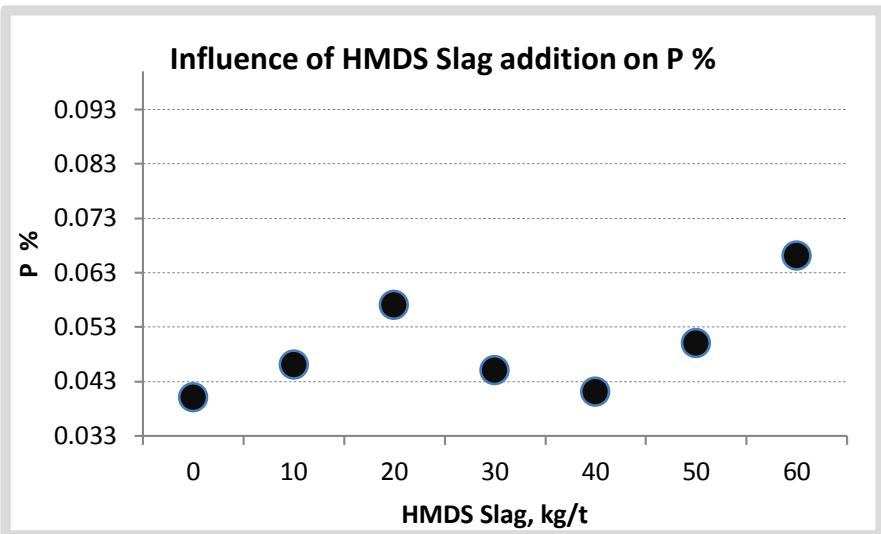

Figure 8:- Influence of HMDS Slag addition on P\%.

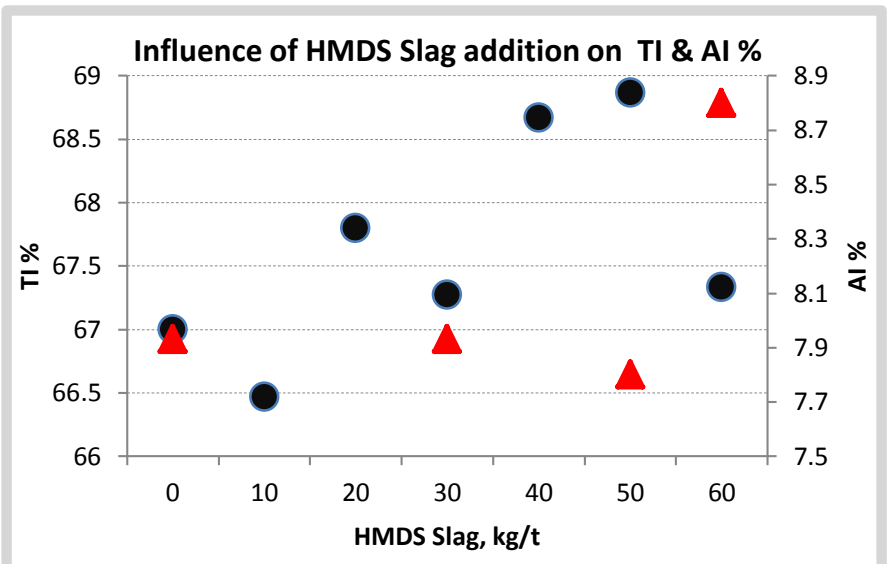

Figure 9:- Influence of HMDS Slag addition on TI \& AI \%. 


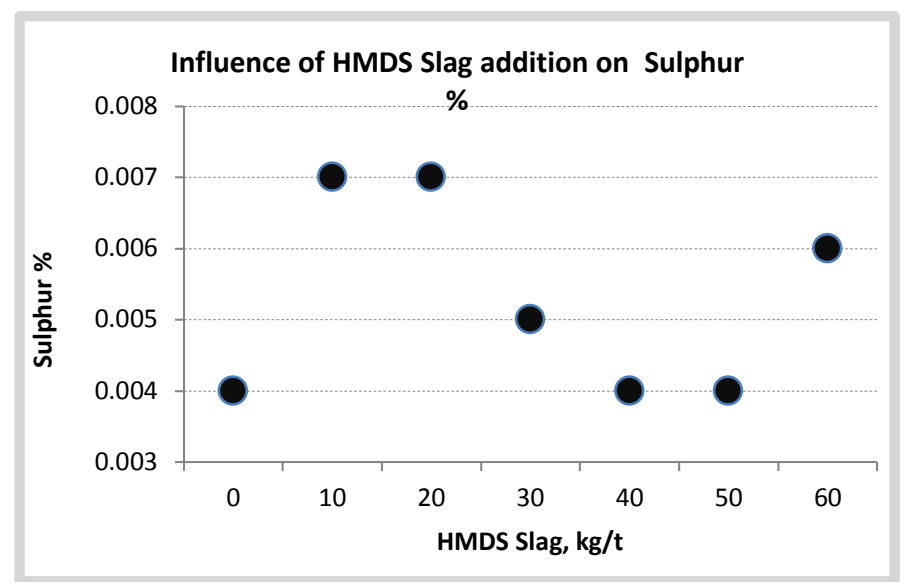

Figure 10:- Influence of HMDS Slag addition on Sulphur \%

\section{Influence of HMDS Slag addition on sinter Strength:-}

Influence of tumbler and abrasion index of the sinter is shown in Figure 6. Tumbler index decreased and abrasion index increased with increase in addition of LD slag. Strength of sinter mainly depends on the phases present in the sinter and melts available for formation of sinter. Usage of limestone in the sinter base mix provides free $\mathrm{CaO}$ after calcination for melt formation and calcium ferrites formation takes place. In case of HMDS Slag $\mathrm{CaO}$ is not available in free form and it is combined with $\mathrm{SiO}_{2}$ and $\mathrm{FeO}$ as dicalcium silicate, dicalcium ferrite and Calciowustite for melt formation. The availability of $\mathrm{CaO}$ phase for assimilation and for melt formation decreases with increase in addition of LD slag. Decrease in availability of free $\mathrm{CaO}$ for melt formation and assimilation leads to formation of less calcium ferrites and poor bonding. Proper assimilation of fluxes with hematite during sintering process gives good mechanical strength [14]. Calcium ferrite is the major mineral constituent of the sinter structure and it imparts strength to the sintered mass. High content of calcium ferrites favors the tumbler strength of the sinter $[15,16]$.influence of HMDS Slag addition on sinter mean particle size and cum $+10 \mathrm{~mm}$ percentage. In the present study sinter mean particle size was not influenced by the HMDS Slag addition. The sinter cum $+10 \mathrm{~mm}$ decreased with increase in HMDS Slag addition. The +10 cum size of the sinter is directly related to the strength of the sinter.

From the test results it was found that maximum 2.5 to $3.0 \%$ (30 to $35 \mathrm{~kg} / \mathrm{t}$ of sinter) HMDS Slag can be used in the sinter making to achieve desired properties of the sinter

\section{Conclusions:-}

1. The FeO content of the sinter decreased with increase in HMDS Slag addition due to decrease in sinter bed temperature.

2. The phosphorous content of the sinter increased with increase in addition of HMDS Slag because HMDS Slag consists of high phosphorous.

3. Limestone percentage in the sinter mix decreased with increase in HMDS Slag addition because the high content of $\mathrm{CaO}$ in the HMDS Slag replaced part of limestone as fluxing material.

4. The sinter productivity increased with increase in addition of LD slag. This is due to decrease in LOI content in the sinter base mix and absence of weight loss due to calcination process.

5. Tumbler index decreased and abrasion index increased with increase in addition of LD slag. This is due to less availability of free $\mathrm{CaO}$ phase for assimilation and melt formation results in poor bonding.

6. The both RDI (-3.15) and RDI $(-0.5 \mathrm{~mm})$ increased with increase in addition of HMDS Slag due to non availability of free $\mathrm{CaO}$ in HMDS Slag reduces the formation of calcium ferrites phase and more $\mathrm{Fe}_{2} \mathrm{O}_{3}$ remains as free phase due to less reaction with $\mathrm{CaO}$.

7. Usage of HMDS Slag up to 30 to $35 \mathrm{~kg} / \mathrm{t}$ of sinter (2.5 to $3.0 \%$ ) in the sinter base mix gives better physical and metallurgical properties of the sinter within the desired value

\section{Acknowledgment:-}

The authors would like to acknowledge JSW Steel Limited, Toranagllu, and Karnataka, India for conducting experiments. Sincere thanks to Mr Ratnakar Bonda who involved in this work. 


\section{References:-}

1. K. M. Goodson, N. Donaghy and R. O. Russsel: Steelmaking Conf. Proc., 481-485; 1995, ISS.

2. C.-J. Liu, Y.-X. Zhu and M.-F. Jiang: Iron Steelmaking, 2003, 30, 36-42.

3. T. Emi: Proc. 6th. Int. Conf. on 'Molten slags, fluxes and salts', Stockholm, June 2000, paper 001.

4. R. Dippenaar, Iron making and Steelmaking, 2005 Vol 32, No 1, p 35.

5. T. W. Miller, J. Jimenez, A. Sharan and D. A. Goldstein: in 'Making, shaping and treating of steel: Steelmaking and refining volume', 11th edn, 514; 1998, AISE Steel Foundation.

6. B. J. Reeves and W.-K. Lu: Proc. 6th. Int. Conf. on 'Molten slags, fluxes and salts', Stockholm, June 2000, paper 201.

7. Francesco Memoli, Osvaldo Brioni, AISTech 2006 Proceedings - Volume II, p 1171

8. W. T. Lankford, N. L. Samways, R. F. Craven and H. E.McGannon (eds.): 'Making, Shaping and Treating of Steel', $10^{\text {th }}$ edn, 333; 1985, Pittsburgh, PA, United States Steel.

9. Sharma KK, Swaroop S, Thakur DS. Recycling of HMDS Slagthrough sinter route on direct charging in blast furnace at Bhilai Steel Plant. In: Proceedings of national seminar on pollution control in steel industries; 1993. p.72-9

10. J. N. Murphy, T. R. Meadowcroft and P. V. Barr: Can. Metall. Q., 1997, 36, 315-331.

11. B. Das, S. Prakash, P.S.R. Reddy and V.N. Mishra: An overview of utilization of slag and sludge from steel industries", Elsevier, Vol 50, (2007), No 1, PP 40-57.

12. Mukerjee, A.K., and Chakra arty, T.K., "Environment and Waste Management in Iron and Steel Industries," 1999, National Metallurgical Laboratory, Jamshedpur, India, pp. 37-49.

13. Manor Kumar choudhary and Bikash nandy: Tata search, 2006, pp 135-139.

14. R.P. Bhagat et al, "Heat transfer consideration for improvement in reducibility and RDI values of sinter" Iron making conference proceedings, 1989, Pp481-490.

15. I. Shigaki, M. Sawada, M. Meakawa, and K. Narita: Trans. Iron steel Inst. Jpn., 22 (1982), pp 838.

16. N. Sakamoto, H. Fukuyo, Y. Iwata and T. Miyashita: Testu - to - Hagane, 70 (1984), pp 40

17. H.P. Pimenta and V. Sheshadri, Iron making and Steelmaking, 29 (2002. 